\title{
Environmental Issues in the History Textbook
}

\author{
Tsabit Azinar Ahmad \\ azinarahmad@mail.unnes.ac.id \\ Department of History, Faculty of Social Sciences, Universitas Negeri Semarang \\ Central Java, Indonesia
}

\begin{abstract}
This paper analyzes the relationship between learning history and environmental issues. The link between history and environmental issues raises a new subdiscipline, namely environmental history. Environmental history looks at how humans have relationships and interact with the environment. In the history class, environmental issues cannot be separated because they are part of the subject matter. But how is the environmental issue narrated? More specifically, this paper analyzes how environmental history is described in Indonesian history textbooks. Have environmental issues received the appropriate portion in Indonesian history textbooks? Through critical discourse analysis, history textbooks for the 2013 curriculum were analyzed. The content of the environmental problems explained in history textbooks includes (1) the environmental ethics of community; (2) patterns of community and environmental interactions; (3) environmental management policies; (4) environmental problems in the past; (5) continuity of current environmental problems with the past.
\end{abstract}

Keywords: environmental history, history textbook, environmental issues.

\section{Introduction}

Environmental issues are currently in the spotlight. This is motivated by the development of the world's population that continues to increase. Until now, the earth has been inhabited by more than 7 billion people. This number will still increase sharply in the next few years. The population increases from year to year will significantly affect the environment in which they live. The population that continues to increase has the potential to affect environmental sustainability significantly. A large community has the potential to support ecological conservation while damaging the environment. A negative potential increase in population can be interpreted as an increase in the number of people who destroy and do not care about environmental conservation.

Rapid human growth according to the potential to cause problems, ranging from conflict to ecological damage. As the scientific revolution develops over the past 500 years, humans and their intelligence are able to climb the top of the food chain. Humans become a factor that also affects the environment. [1] So not surprisingly, human intervention on the earth contributes to climate 
change. This problem has driven various global policies, such as the Kyoto Protocol to sustainable development goals.

Efforts to sustain various global policies on environmental issues are carried out by implementing environmental education. Environmental education aims to increase knowledge, skills, and awareness about environmental values and environmental issues for students. The hope, this education can move students to play an active role in environmental conservation activities for sustainable living. [2]

The implementation of environmental education can be applied to all subjects. It is because environmental education is multidisciplinary. [3] Environmental education does not only talk about biological disciplines and matters relating to physical aspects. He also spoke about the aesthetic, economic, political, social, historical, and cultural perspectives. [4]

One point related to environmental issues is history. Therefore, the subjects of Indonesian history have relevance as part of environmental education. It is reinforced by the emergence of new disciplines in history, namely environmental history in the 1970s. This study of environmental history is the subject of history lessons. [5]

History education has a strategic role in mainstreaming ecological issues. First, history education helps reveal the relationship and reciprocity between humans and the environment. It includes how the environment becomes a variable that determines the development of human civilization. Second, history education explains the development of the relationship pattern between humans and the environment. This study covers changes in patterns of social interaction and the environment from time to time. Third, history education explains the current development of environmental issues. Through learning history, students understand the root causes of environmental problems currently faced. [5]

However, there have not been many studies on environmental issues in learning Indonesian history. The comments that have been carried out so far are more comforting about conceptual frameworks, such as the idea of learning environmental history [5] and the urgency of ecopedagogy and green history.[6] The study of environmental issues narrated in Indonesian history textbooks has not yet been conducted. Therefore, this paper aims to analyze the content of Indonesian history textbooks in terms of ecological issues in it.

\section{Methodology}

The study uses a discourse analysis strategy on Indonesian history textbooks. The book used is an official issue from the Ministry of Education and Culture for the 2013 curriculum. The books analyzed is a history book for students of class X, XI, and XII revised editions and some curriculum documents. Documents used as the basis of the analysis is Peraturan Menteri Pendidikan dan Kebudayaan Nomor 59 Tahun 2014 tentang Kurikulum 2013 Sekolah Menengah Atas/Madrasah Aliyah (Minister of Education and Culture Regulation Number 59 the Year 2014 concerning 2013 High School / Madrasah Aliyah Curriculum) and Peraturan Menteri Pendidikan dan Kebudayaan Nomor 24 Tahun 2016 tentang Kompetensi Inti dan Kompetensi Dasar Pelajaran pada Kurikulum 2013 pada Pendidikan Dasar dan Pendidikan Menengah (Minister of Education and Culture Regulation Number 24 the Year 2016 concerning Core Competencies and Basic Learning Competencies in 2013 Curriculum on Basic Education and Secondary Education). 
Indicators in the textbook analysis include aspects (1) the environmental ethics of community; (2) patterns of community and environmental interactions; (3) environmental management policies; (4) environmental problems in the past; (5) continuity of current environmental problems with the past.

\section{The Results and Discussions}

\subsection{The Curricular Relevance of Environmental Issues in Indonesian History Lessons}

The integration of the value of environmental care does not necessarily appear in the 2013 curriculum. It has its roots in the 2006 curriculum. In the 2006 curriculum, it was explained explicitly that historical material "berguna untuk menanamkan dan mengembangkan sikap bertanggung jawab dalam memelihara keseimbangan dan kelestarian lingkungan hidup" (useful for instilling and developing a responsible attitude in maintaining environmental balance and sustainability. [7] This was then continued in the 2013 curriculum.

The 2013 curriculum emphasizes the importance of character education for students. It is stated by the existence of core competencies that include aspects of spiritual attitudes, social attitudes, knowledge, and skills. [8][9] In the kompetensi inti (core competency) 2 is writen "Mengembangkan perilaku (jujur, disiplin, tanggung jawab, peduli, santun, ramah lingkungan, gotong royong, kerjasama, cinta damai, responsif dan proaktif) dan menunjukan sikap sebagai bagian dari solusi atas berbagai permasalahan bangsa dalam berinteraksi secara efektif dengan lingkungan sosial dan alam serta dalam menempatkan diri sebagai cerminan bangsa dalam pergaulan dunia." (Developing behavior (honesty, discipline, responsibility, caring, polite, environmentally friendly, mutual cooperation, cooperation, love peace, responsive and proactive) and show attitude as part of the solution to various national problems in interacting effectively with the social and natural environment and in placing themselves as a reflection of the nation in the world association). Initially, these core competencies were developed into specific basic competencies. For example, for class X, there are basic competencies "2.2. Meneladani sikap dan tindakan cinta damai, responsif dan proaktif yang ditunjukkan oleh tokoh sejarah dalam mengatasi masalah sosial dan lingkungannya." (Exemplify the attitudes and actions of peaceloving, responsive and proactive shown by historical figures in overcoming social and environmental problems) [9]

However, in 2016, the curriculum underwent a revision. The impact is that there are no specific basic competencies that describe social core competencies. In the change of this curriculum, social attitudes are achieved through indirect teaching. [8] The impact is that formally, the basic competencies formulated only cover aspects of knowledge and skills. Therefore, the internalization of environmental ethics is integrated into the basic competencies of knowledge and skills.

If analyzed, some basic competencies are relevant to environmental issues. Some of the basic competencies are as follows. 
Table 1. The Linkage between Basic Competencies and the Field of Environmental History Studies

\begin{tabular}{|c|c|c|}
\hline Grade & Basic Competence & Relevant Field of Study \\
\hline \multirow[t]{4}{*}{$\mathrm{X}$} & $\begin{array}{l}\text { 3.3. analyze the lives of ancient } \\
\text { humans and the origins of the ancestors } \\
\text { of the Indonesian people (melanesoid, } \\
\text { proto, and deutero Malay) }\end{array}$ & $\begin{array}{l}\text { - the environmental ethics of } \\
\text { community } \\
\text { - patterns of community and } \\
\text { environmental interactions }\end{array}$ \\
\hline & $\begin{array}{l}\text { 3.4. understand the results and } \\
\text { cultural values of prehistoric } \\
\text { Indonesian communities and their } \\
\text { influence in the lives of the nearest } \\
\text { environment }\end{array}$ & 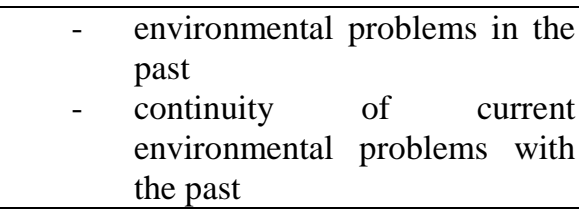 \\
\hline & $\begin{array}{l}\text { 3.6. analyze the development of } \\
\text { community life, government, and } \\
\text { culture during the Hindu and Buddhist } \\
\text { kingdoms in Indonesia and show } \\
\text { examples of evidence that still applies } \\
\text { to the life of Indonesian society today }\end{array}$ & $\begin{array}{l}\text { - the environmental ethics of } \\
\text { community } \\
\text { patterns of community and } \\
\text { environmental interactions } \\
\text { - environmental management } \\
\text { policies } \\
\text { - environmental problems in the } \\
\text { past }\end{array}$ \\
\hline & $\begin{array}{l}\text { 3.8. analyze the development of } \\
\text { community life, government, and } \\
\text { culture during the Islamic empires in } \\
\text { Indonesia and show examples of } \\
\text { evidence that still applies to the life of } \\
\text { Indonesian society today }\end{array}$ & $\begin{array}{l}\text { - the environmental ethics of } \\
\text { community } \\
\text { - patterns of community and } \\
\text { environmental interactions } \\
\text { - environmental management } \\
\text { policies } \\
\text { - environmental problems in the } \\
\text { past }\end{array}$ \\
\hline $\mathrm{XI}$ & $\begin{array}{l}3.3 \text { analyze the political, cultural, } \\
\text { social, economic, and educational } \\
\text { impacts of European colonial times } \\
\text { (Portuguese, Spanish, Dutch, English) } \\
\text { in the lives of today's Indonesian } \\
\text { people }\end{array}$ & 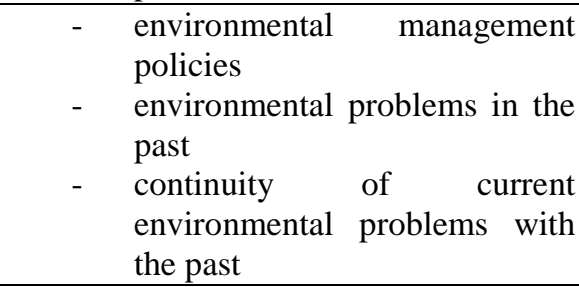 \\
\hline XII & $\begin{array}{l}\text { 3.9. evaluate the life of the } \\
\text { Indonesian people in developing } \\
\text { science and technology in the era of } \\
\text { independence (from the proclamation } \\
\text { to the Reformation) }\end{array}$ & 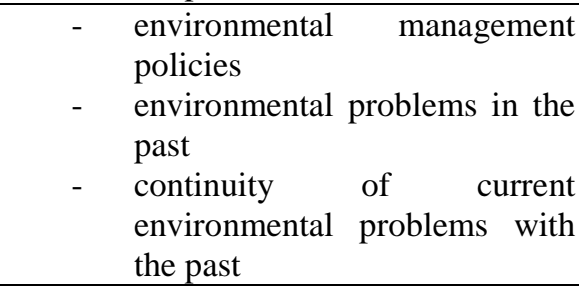 \\
\hline
\end{tabular}


The information above shows that environmental issues are actually closely related to the material in Indonesian History lessons.

\subsection{Environmental Issues in Indonesian History Textbook}

The relevance of the basic competencies in Indonesian history lessons and the field of environmental history studies shows that environmental issues can be part of the historical subject matter. To find out more about how the two are related, analyzed textbooks published by the Ministry of Education and Culture for classes X, XI, and XII.

In class $\mathrm{X}$, there are quite a lot of environmental aspects. The scope of material in class $\mathrm{X}$ is more about environmental conditions in prehistoric times. The narrative about environmental ethics and the relationship between the context of the past and the present. On page 6, it is explained that the ethics of ancient people's life view that of the harmonious relationship between humans and nature. In the next section in the concluding chapter on page 70, it is explained about how the difference between the environmental ethics of prehistoric and modern societies. In the passage, it is written "Tim Flannery menyebut manusia Homo sapiens zaman modern berbeda dengan nenek moyang mereka, karena mereka tidak lain adalah "pemangsa masa depan". Julukan ini tidak salah apabila kita menghitung kembali kerusakan lingkungan yang diakibatkan oleh eksploitasi manusia hingga saat ini." (Tim Flannery team calls modern-day Homo sapiens people different from their ancestors because they are none other than" future predators). This nickname is not wrong if we recalculate the environmental damage caused by human exploitation to date. [10] This narrative indicates that it was in modern times that environmental damage occurred, while prehistoric societies had a harmonious relationship with nature. The prehistoric environmental problems narrated in this book are mostly caused by natural disasters such as volcanic eruptions, not human actions. However, the scope of environmental issues in the section on traditional kingdoms in class $\mathrm{X}$ is not yet apparent. Several events can be raised, such as the construction of canals during the Tarumanegara kingdom and the development of the Sriksetra park by the Sriwijaya kingdom for catchment areas.

In the book class XI Semester 1, the environmental issues highlighted are still not many. Amid the fairness of environmental issues raised, on pages 103-104 it was written that environmental problems were one of the causes of the first Tondano war in Minahasa in 1808. In this book, it was written that flooding due to damming the Temberan River water caused damage to homes and agricultural land. As a result, there was resistance from the community against the Dutch people. Environmental issues are still not optimally described. [11] Some policies and issues concerning the environment have also not been found. Whereas based on Nawiyanto's research, environmental issues are an integral part of colonial to modern history. [12],[13] Then, in semester 2, environmental issues were hardly mentioned in the Indonesian History textbook. Here it only emphasizes the events of the Japanese occupation, the beginning of independence, and the revolutionary period. [14]

In class XII, environmental issues appear in discussions about the development of science and technology in Indonesia. Described here about the green revolution and the impact of technology on people's lives. However, the discussion about these two matters has not yet touched on the environmental problems faced. Narratives about the green revolution still have a lot to say about 
the success of the program. Similarly, the narrative about the impact of technology only talks about how gadgets change people's mindsets. Meanwhile, how environmentally friendly policies and technologies have not been part of this book. [15]

\section{Conclusions}

Environmental issues have a curricular relationship with the learning of Indonesian history. Some basic competencies can be integrated with environmental issues. However, environmental issues, as intended, have not been optimally narrated in textbooks. The biggest portion of environmental issues is discussed in class $\mathrm{X}$ textbooks about prehistoric life. Here narrated about environmental ethics, patterns of interaction, and the continuity of current environmental problems with the past. In class XI, environmental issues raised were more towards the problem of confusion at the time. Meanwhile, in class XII, there is still not much discussion about environmental issues.

\section{References}

[1] Y. N. Harari, Sapiens. Jakarta: Kepustakaan Populer Gramedia, 2019.

[2] D. L. Setyawati, M. Rahayuningsih, and T. A. Ahmad, "Pengembangan Bahan Ajar Pendidikan Lingkungan Hidup Berkarakter di Universitas Negeri Semarang," Indones. J. Conserv., vol. 2, no. 1, pp. 33-44, 2013.

[3] A. G. Cole, "Expanding the Field: Revisiting Environmental Education Principles Through Multidisciplinary Frameworks," J. Environ. Educ., vol. 38, no. 2, pp. 35-45, Jan. 2007.

[4] D. Tilbury, "Environmental Education for Sustainability: defining the new focus of environmental education in the 1990s," Environ. Educ. Res., vol. 1, no. 2, pp. 195-212, Jan. 1995.

[5] T. A. Ahmad, "Pembelajaran Sejarah Berwawasan Lingkungan," Indones. J. Conserv., vol. 2, no. 1, pp. 74-83, 2013.

[6] N. Supriatna and et.al., Ecopedagogy: Membangun kecerdasan ekologis dalam Pembelajaran IPS. Bandung: Remaja Rosdakarya, 2016.

[7] Peraturan Menteri Pendidikan Nasional Nomor 22 tahun 2006 tentang Standar Isi untuk Satuan Pendidikan Dasar dan Menengah. 2006.

[8] Peraturan Menteri Pendidikan dan Kebudayaan nomor 24 Tahun 2016 Tentang Kompetensi Inti Dan Kompetensi Dasar Pelajaran Pada Kurikulum 2013 Pada Pendidikan Dasar Dan Pendidikan Menengah. 2016.

[9] Peraturan Menteri Pendidikan dan Kebudayaan Nomor 59 tahun 2014 tentang Kurikulum 2013 Sekolah Menengah Atas/Madrasah Aliyah. 2014. 
[10] R. Hapsari and M. Adil, Sejarah Indonesia untuk SMA/MA Kelas X Kelompok Wajib. Jakarta: Penerbit Erlangga, 2016.

[11] Sardiman and A. D. Lestariningsih, Sejarah Indonesia untuk SMA/MA/SMK/MAK Kelas XI Semester I, Edisi Revi. Jakarta: Kementerian Pendidikan dan Kebudayaan RI, 2017.

[12] Nawiyanto, “Gerakan Lingkungan Di Jawa Masa Kolonial," Paramita Hist. Stud. J., vol. 24, no. 1, pp. 51-72, 2014.

[13] Nawiyanto, "Berjuang Menyelamatkan Lingkungan: Gerakan Lingkungan di Jawa masa Kemerdekaan 1950-2000," Paramita Hist. Stud. J., vol. 25, no. 1, pp. 51-72, 2015.

[14] Sardiman and A. D. Lestariningsih, Sejarah Indonesia untuk SMA/MA/SMK/MAK Kelas XI Semester 2, Edisi Revi. Jakarta: Kementerian Pendidikan dan Kebudayaan RI, 2017.

[15] R. Hapsari and M. Adil, Sejarah Indonesia untuk SMA/MA Kelas XI Kelompok Wajib. Jakarta: Penerbit Erlangga, 2016. 